Portland State University

PDXScholar

Jul 25th, 3:05 PM - 3:25 PM

\title{
Flashlight: Using Bizup's BEAM to Illuminate the Rhetoric of Research
}

Kate Rubick

Lewis \& Clark College

Follow this and additional works at: https://pdxscholar.library.pdx.edu/liw_portland

Part of the Information Literacy Commons

Let us know how access to this document benefits you.

Rubick, Kate, "Flashlight: Using Bizup's BEAM to Illuminate the Rhetoric of Research" (2014). Library Instruction West 2014. 10.

https://pdxscholar.library.pdx.edu/liw_portland/Presentations/Material/10

This Event is brought to you for free and open access. It has been accepted for inclusion in Library Instruction West 2014 by an authorized administrator of PDXScholar. Please contact us if we can make this document more accessible: pdxscholar@pdx.edu. 


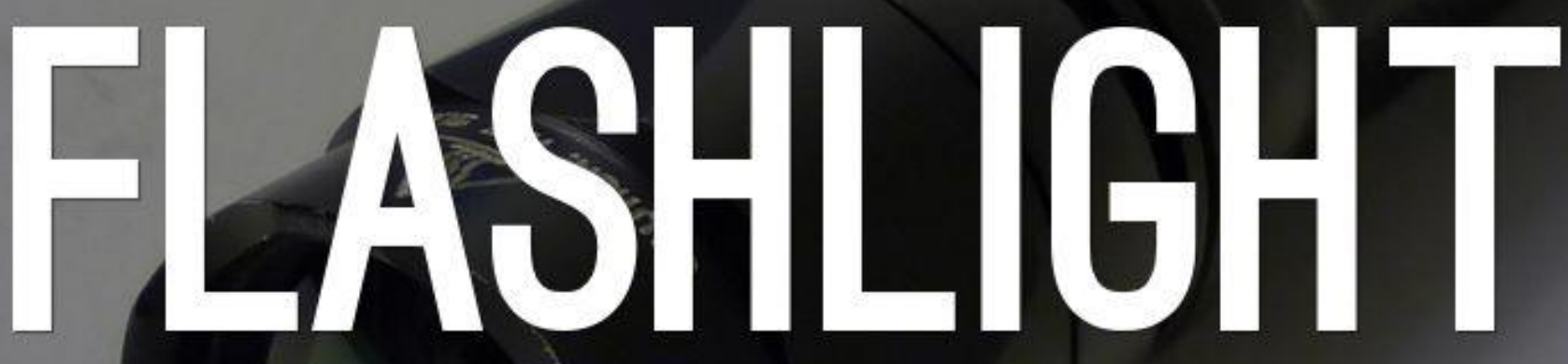

USING BIZUP'S BEAM TO ILLUMINATE THE RHETORIC OF RESEARCH 


\section{THE \\ CLASSIC \\ QUESTION}

WHAT IS A PRIMARY SOURCE?

(c) Photo by just.Luc - Creative Commons Attribution-NonCommercial-ShareAlike License https:/www.flickr.com/photos/9619972@N08 


\section{RESEARGH ASSIGNMENT}

1. Three academic books

2. Five peer reviewed journal articles

3. no more than two websites

4. no Wikipedia! 


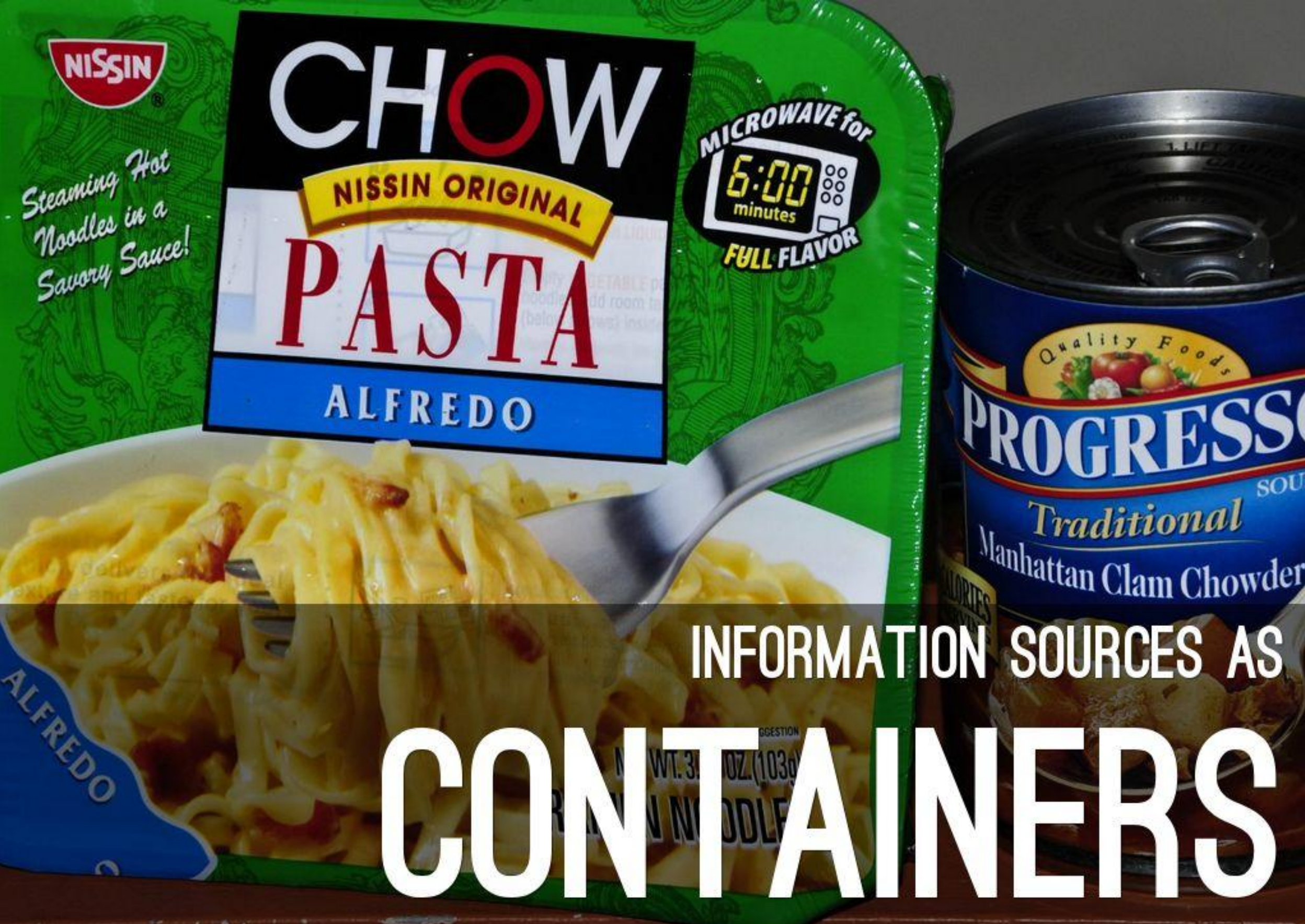




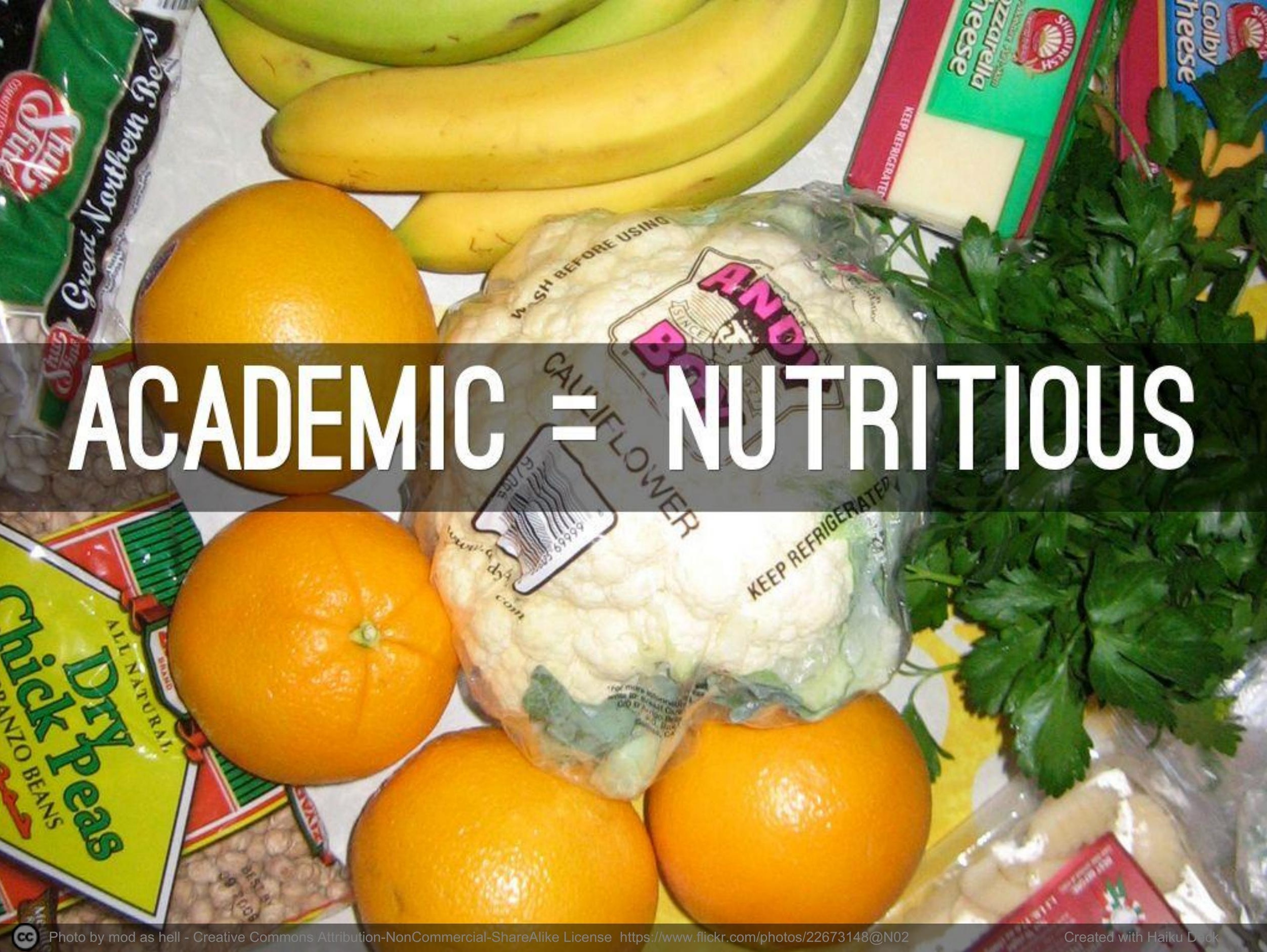




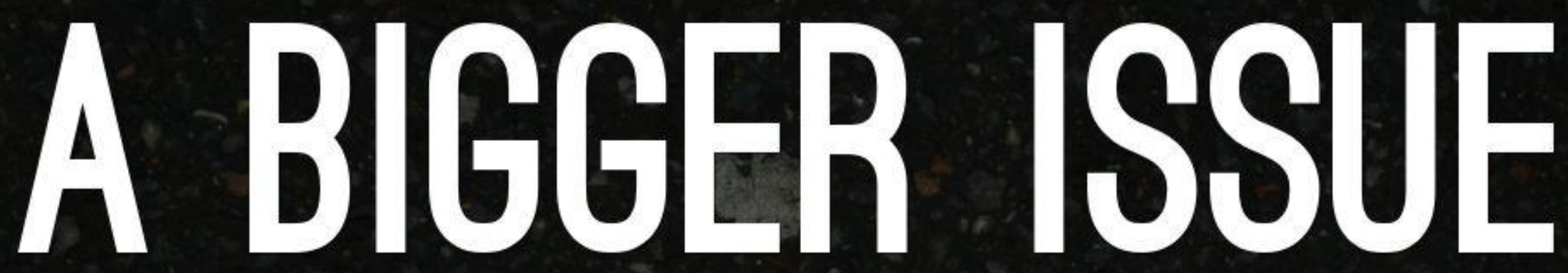

WHAT DO WRITERS DO WITH SOURCES?

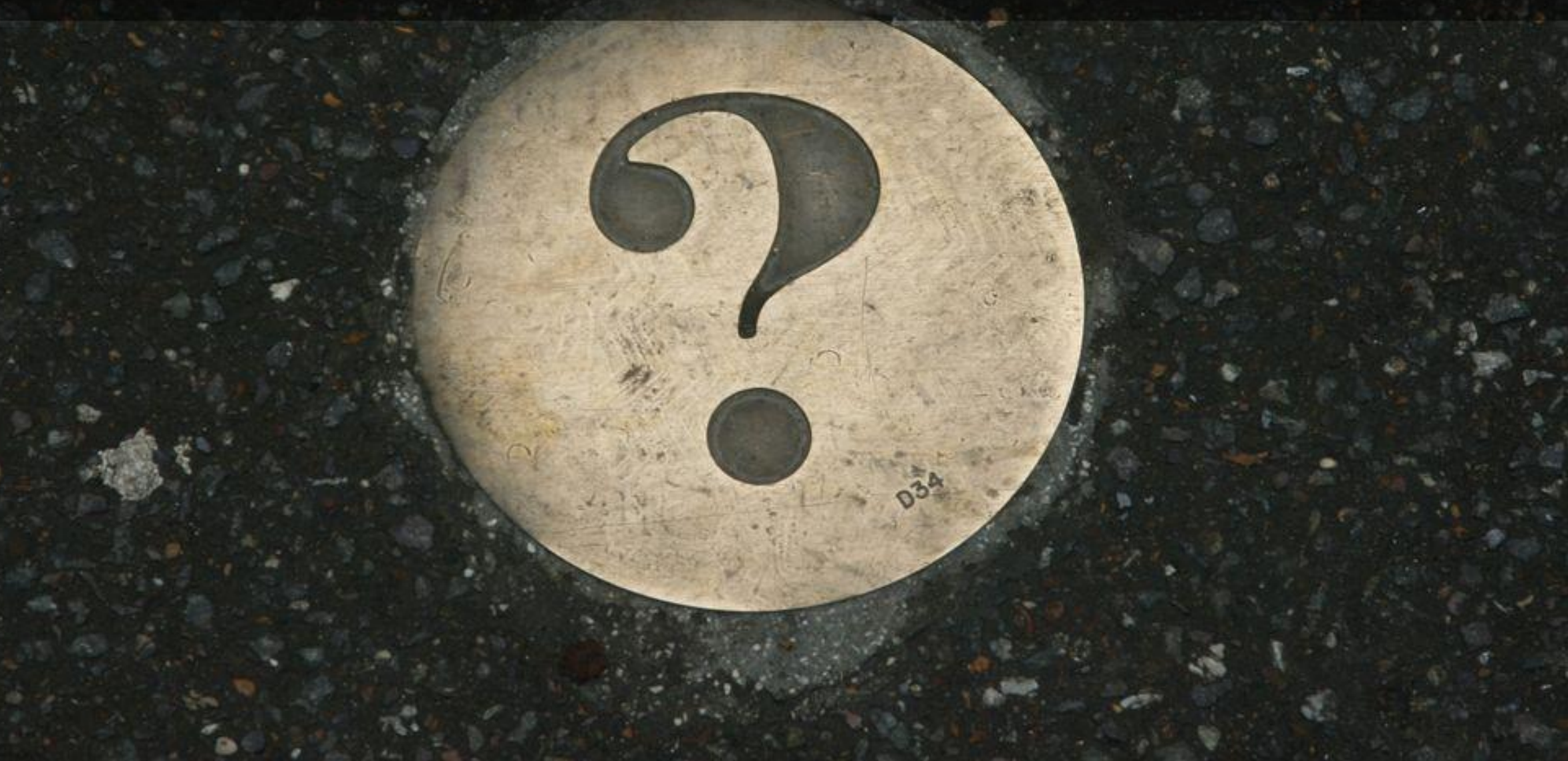



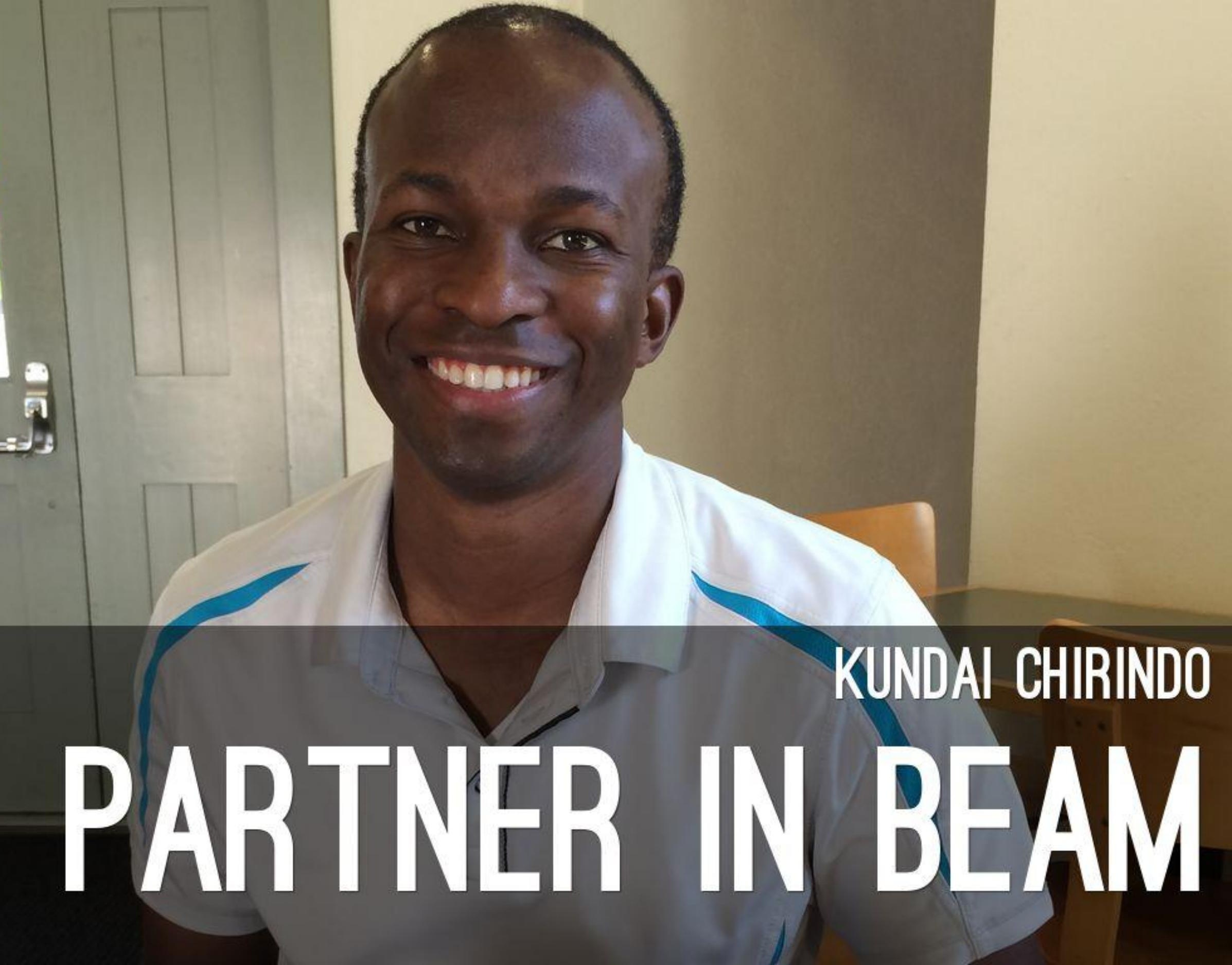


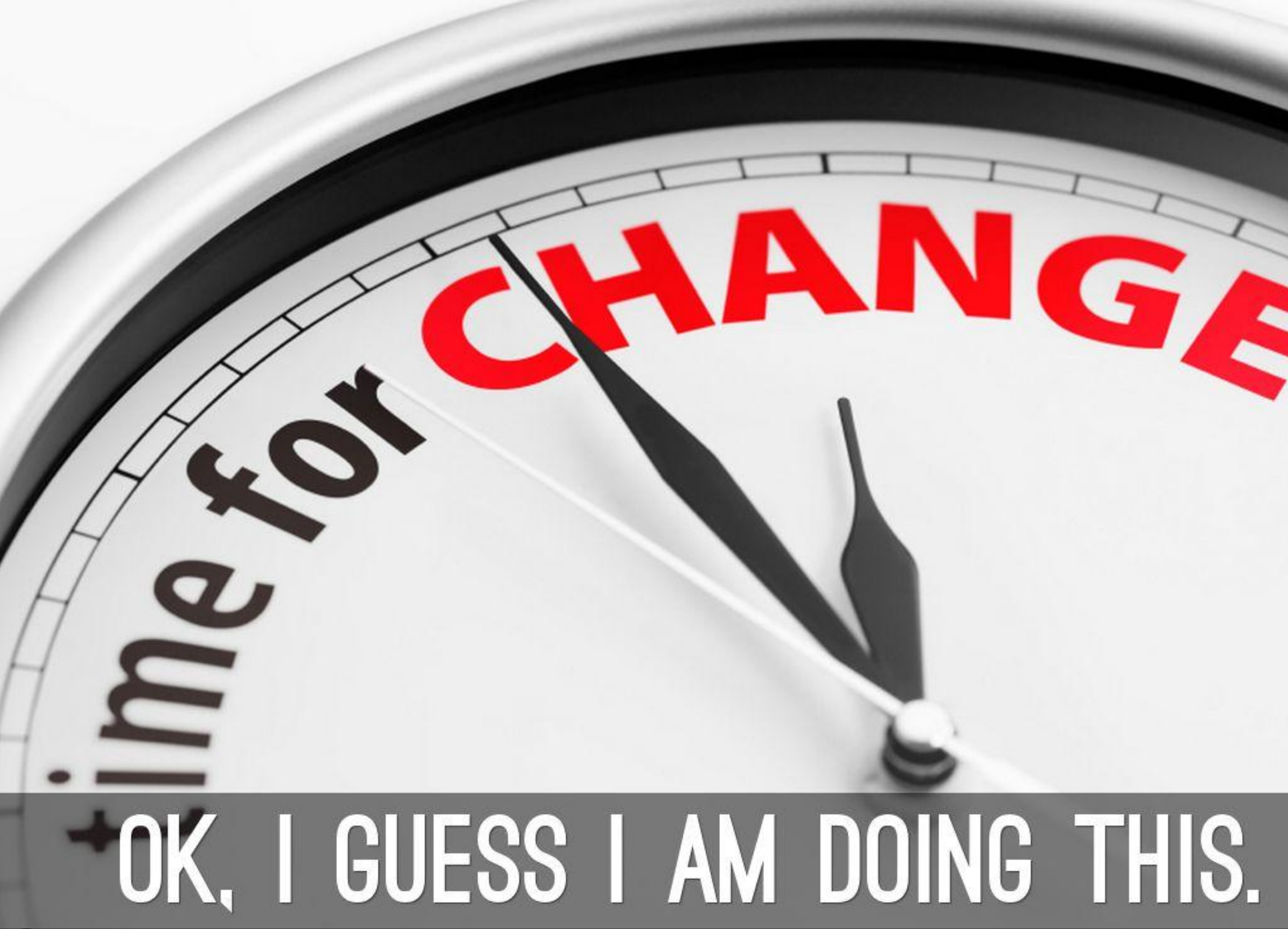

(c) Photo by marsmet546 - Creative Commons Attribution-NonCommercial-ShareAlike License https://www.flickr.com/photos/90585146@N08 
LEGITIMIZING WIKIPEDIA
newspapers frame and use How US nationalopedia the online end jeff south

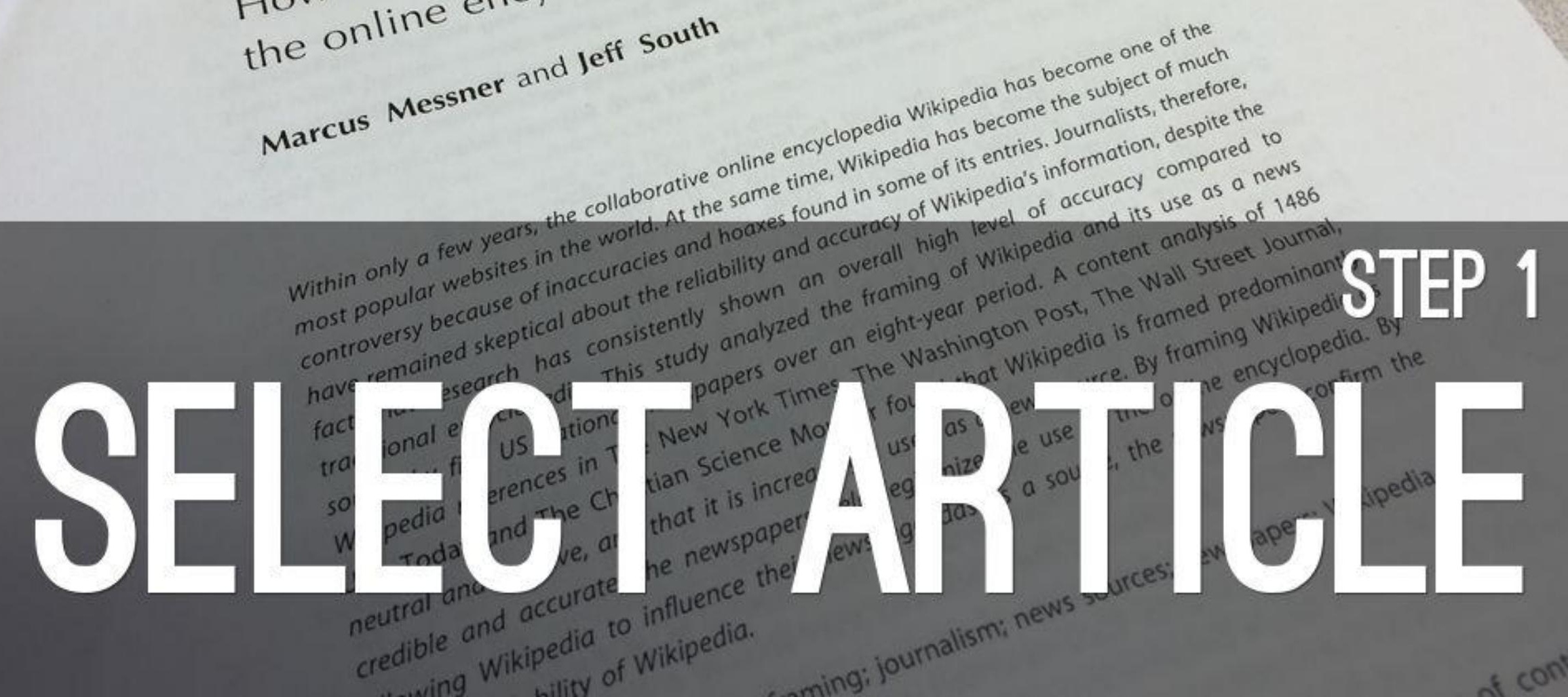


Wikipedia itself. The list was created bilation of citations, however, is the same as with comprehensive collection.

Previous research has not attempted to systematically quantify and evaluate the use of Wikipedia as a news source nn a hroad ar -ale. Try ..... study, therefore, was to

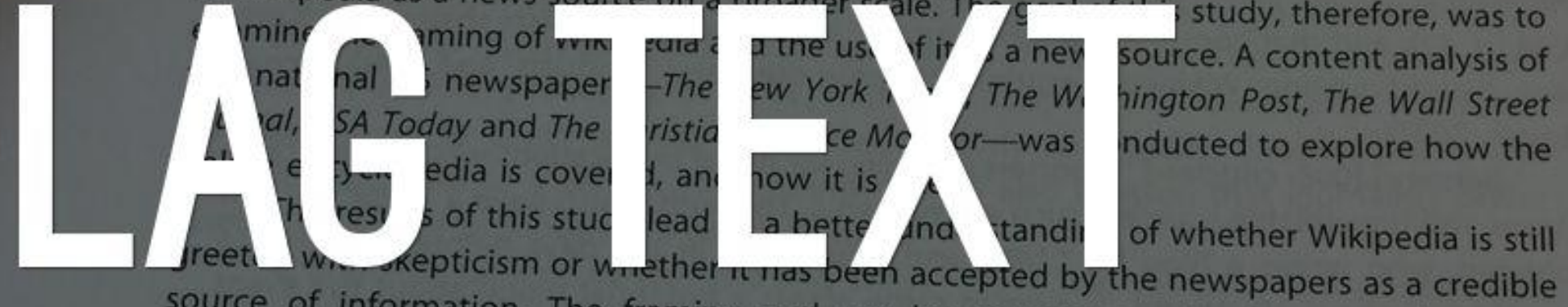
source of information. The framing and use by newspapers also has agenda-setting implications on the public's view on Wikipedia, as certain frames of media coverage and news sources have the potential to shape public opinion. Overall, this study helps to evaluate the level of legitimization for Wikipedia.

\section{Framing of Wikipedia}

McCombs (2005) defined five stages of agenda-setting theory: (1) issue agendasetting, (2) attribute agenda-setting, (3) psychology of agenda-setting effects, (4) sources of the media agenda, and (5) consequences of agenda-setting. This study explores two of these areas: how attributes in media coverage frame the online encyclopedia Wikipedia, and how the media use it as a source.

According to Gamson (1989), framing theory helps to analyze how certain attributes of information are emphasized over others. It is important to understand how the media frame an issue when there are a variety of options to present the information. The selection of specific facts and their interpretation have the potential to shape public opinion and influence the public's agenda (Mahon and Wartick, 2003). When journalists choose a frame for an issue, they make a consequential decision that will influence the story, but also its reader's perception of the issue (McCombs and Shaw, 1993). Wanta et al. (2004) stressed that the public learns the importance of an iccus hacod 


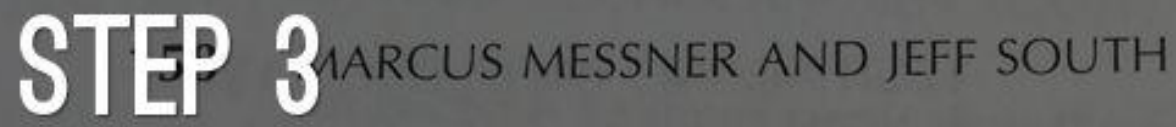

FINNEY, PAUL. B. (2007) "Redefining Business Casual", The New York Times, http://www.nytimes

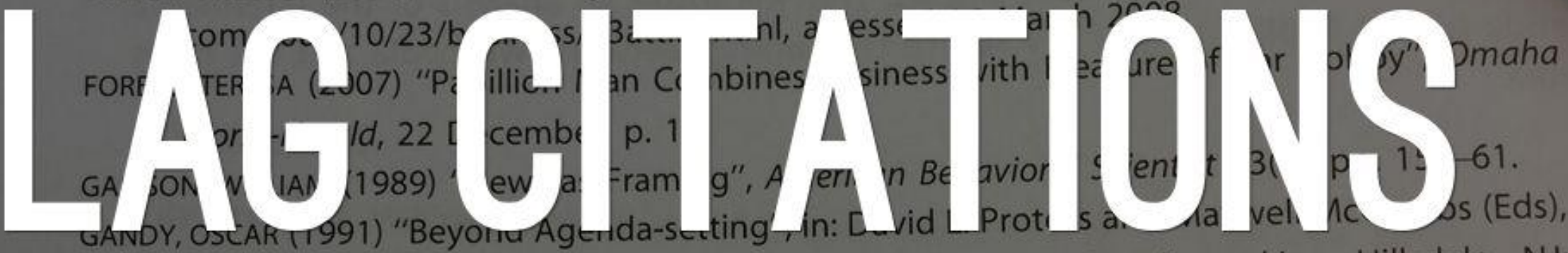
Agenda Setting: readings on media, public opinion, and policymaking, Hillsdale, NJ: Lawrence Erlbaum Associates.

GANS, HERBERT J. (2003) Democracy and the News, New York: Oxford University Press.

GILES, JIM (2005) "Internet Encyclopedias Go Head to Head", Nature 438, pp. 900-1.

GOLDMAN, JIM (2008) "Steve Jobs' Macworld Speech Leaked or Big Hoax?", CNBC, http:// www.cnbc.com/id/22664083/Steve_Jobs_Macworld_Speech_Leaked_Or_Big_Hoax, accessed 26 March 2008.

GUENTHEROTH, HORST and SCHOENERT, ULF (2007) "Wikipedia: Wissen fuer alle", Stern, http:// www.stern.de/digital/online/wikipedia-wissen-fuer-alle-606048.html, accessed 26 March 2008.

HALAVAIS, ALEXANDER and LACKAFF, DEREK (2008) "An Analysis of Topical Coverage of Wikipedia", Journal of Computer-mediated Communication 13(2), pp. 429-40.

HENNINGER, DANIEL (2007) "Bong Hits 4 Jesus explained", The Wall Street Journal, http:// WWW.wsj.com, accessed 25 March 2008.

HOVLAND, CARL I. and WEISS, WALTER (1951) "The Influence of Source Credibility on Communication Effectiveness", Public Opinion Quarterly 15, pp. 635-50.

IBELEMA, MINEABERE and POWELL, LARRY (2001) "Cable Television News Viewed as Most Credible", 


\section{CLASS OUTLINE}

1. Introduce library services for RHMS

2. Discussion of Bizup article

3. Application of BEAM 


\section{APPLICATION OF BEAM}

1. Distribute flagged articles

2. Student volunteer reads abstract

3. Independent analysis

4. Groups of three discuss

5. Groups report out 


\section{HOW IT WENT}

- Students engaged

- Students reticent

- Aha moment 


\section{OUTCOMES}

- 19 research consultations

- Quality of papers increased

- A professor converted

- An effective inroads established 


\section{REFLECTION}

- BEAM for reading AND writing

- BEAM for practicing rhetorical criticism

- Application for other disciplines? 


\section{OTHER LIBRARIES USING BEAM}

Bard High School Early College - Manhattan Brookdale Community College California State University Maritime The George Washington University High Point University

Illinois Wesleyan University

St. Olaf College Portland State University University of Baltimore University of Colorado Boulder University of Wisconsin Milwaukee Westminster College Worcester State University 


\section{IMAGE SOURCES}

Self portrait of Joseph Bizup, used with permission.

What could a writer do with this source? by Kristin M. Woodward/Kate L. Ganski is licensed under a Creative Commons Attribution-NonCommercialShareAlike 4.0 International License.

Portrait of Kundai Chírindo by Kate Rubick.

Other images used with cc license via haiku deck. 


\section{REFERENCES}

Bizup, J. 2008, "BEAM: A rhetorical vocabulary for teaching research-based writing", Rhetoric review, vol. 27, no. 1, pp. $72-86$.

Fister, B. 2013, July 18,2013 last update, Welcome to the Palace of Ambiguity [Homepage of Inside Higher Ed Library Babel Fish], [Online]. Available:

http://Www.insidehighered.com/blogs/library/babelfish/welcome-palace-ambiguity \#sthash.pRdtrmUv.dplos [2014, July 17,2014].

Gangski, K. 2013, March 28, 2013-last update, Flipping Freshman Composition Library Instruction [Homepage of My So Called Librarian Life], [Online]. Available: http://ganski.wordpress.com/2013/03/28/flipping-freshmancomposition-library-instruction/ [2014, July 17], is.s: 


\section{REFERENCES (CONTINUED)}

Jones, M. 2012, "Teaching Research Across Disciplines: Interdisciplinarity and Information Literacy in interdisciplinarity and academic librâries, eds. D.C. Mack \& C.|Gibsón, Association of College and Research 4 ibraries, a division of the Americal Library Association,

$$
\text { pp. } 167-181 \text {. }
$$

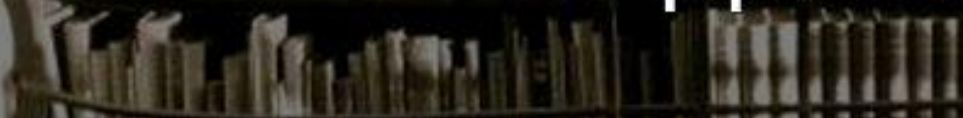

Messner, M. 2011," "Legitimizing Wikipedia: How US national hewspapers framle and use the online encyclopedia in their coverage, Journalism practice, vol. 5, no. 2, p. $.145-160$. 



\section{CONTACT}

\section{Kate Rubick \\ Instruction Services Librarian Aubrey R. Watzek Library Lewis \& Clark College rubick at Iclark dot edu

